Reply

\title{
Reply to Ortner
}

\section{Josef Schosser}

Faculty of Business Administration and Economics, University of Passau, 94030 Passau, Germany; josefschosser01@gmail.com

Received: 9 November 2018; Accepted: 12 November 2018; Published: 15 November 2018

Abstract: I address the comments made by Ortner (Games 9(4): 93, 2018) in relation to my note "Incentive Systems for Risky Investment Decisions Under Unknown Preferences: Ortner et al. Revisited" (Games 9(2): 26, 2018).

Keywords: investment decision; performance measure; relative benefit cost allocation

JEL Classification: D82; G31; M46

Ortner et al. [1] examine how to provide consistent incentives for value-maximizing risky investment decisions in settings containing unknown time and risk preferences related to the manager. They propose using a residual income-based performance evaluation together with a state-dependent cost allocation corresponding to the so-called State-Contingent Relative Benefit Cost Allocation (RBCA) Scheme. In a note on this article, I revisit the analysis of Ortner et al. [1] and reveal the information distribution implicitly supposed [2]. It is shown that the expected net present value of the project, which equals the principal's objective function, is known to the principal upon realization of the first cash flow and can thus be used to construct adequate incentive systems. As compared with the mentioned solution according to Ortner et al. [1], these incentive systems are both simpler and more powerful.

In a comment on my note, Ortner [3] confirms and adds to these findings. The properties of my solution [2] can only be replicated if the allocation of costs according to the State-Contingent RBCA Scheme is supplemented by a specific allocation of cash flows (Reference [3] p. 4). In contrast, using the incentive systems proposed in my note [2], there is no need to think about the allocation of cash flows or costs, nor about the calculation of residual incomes.

Ortner et al. (Reference [1] p. 47) state that their paper "gives justification for the use of residual income as a performance measure for management incentive systems". I think they are wrong. With respect to the context developed by Ortner et al. [1], I fail to see why one should use residual income-based performance measures. A meaningful extension of the incentive problem introduced by Rogerson [4] and Reichelstein [5] to the case of potentially risk-averse decision makers requires a different, probably more complex, framework. Special attention should be paid to the modeling of both the cash flow dynamics and the information distribution.

Funding: This research received no external funding.

Acknowledgments: I would like to acknowledge financial support by institutions through the Knowledge Unlatched initiative for open access publishing. I am also grateful to the editors for helpful comments and suggestions.

Conflicts of Interest: The author declares no conflict of interest. 


\section{References}

1. Ortner, J.; Velthuis, L.; Wollscheid, D. Incentive systems for risky investment decisions under unknown preferences. Manag. Account. Res. 2017, 36, 43-50. [CrossRef]

2. Schosser, J. Incentive systems for risky investment decisions under unknown preferences: Ortner et al. revisited. Games 2018, 9, 26. [CrossRef]

3. Ortner, J. Comment on Schosser (2018) “Incentive Systems for Risky Investment Decisions under Unknown Preferences: Ortner et al. Revisited". Games 2018, 9, 93 [CrossRef]

4. Rogerson, W.P. Intertemporal cost allocation and managerial investment incentives: A theory explaining the use of economic value added as a performance measure. J. Political Econ. 1997, 105, 770-795. [CrossRef]

5. Reichelstein, S. Investment decisions and managerial performance evaluation. Rev. Account. Stud. 1997, 2, 157-180. [CrossRef]

(c) 2018 by the author. Licensee MDPI, Basel, Switzerland. This article is an open access article distributed under the terms and conditions of the Creative Commons Attribution (CC BY) license (http:/ / creativecommons.org/licenses/by/4.0/). 